\title{
Dimethylglycine sodium salt protects against oxidative damage and mitochondrial dysfunction in the small intestines of mice
}

\author{
KAIWEN BAI $^{1}$, LUYI JIANG ${ }^{2}$, SHANLI ZHU ${ }^{3}$, CHENGCHENG FENG $^{1}$, \\ YONGWEI ZHAO $^{1}$, LILI ZHANG ${ }^{1}$ and TIAN WANG ${ }^{1}$ \\ ${ }^{1}$ College of Animal Science and Technology, Nanjing Agricultural University, Nanjing, Jiangsu 210095; \\ ${ }^{2}$ College of Animal Science, Zhejiang University, Hangzhou, Zhejiang 310058, P.R. China; \\ ${ }^{3}$ College of Agriculture and Life Science, Department of Animal Science, Cornell University, Ithaca, NY 14853, USA
}

Received August 2, 2018; Accepted February 7, 2019

DOI: $10.3892 /$ ijmm.2019.4093

\begin{abstract}
Few studies have investigated the use of dimethylglycine sodium salt (DMG-Na) to protect against small intestinal damage, despite its prevalence in the treatment of human diseases. The present study aimed to evaluate the protective effects of DMG-Na against oxidative damage and mitochondrial dysfunction in the small intestines of mice. A total of 100 male Kunming mice were randomly assigned to five groups ( $n=20$ per group): i) Mice gastric intubation with $0.3 \mathrm{ml}$ sterile saline solution (once), then subcutaneously injected with sterile saline solution $(0.5 \mathrm{ml})$ after $1 \mathrm{~h}(\mathrm{CON})$; ii) mice gastric intubation with $12 \mathrm{mg}$ DMG-Na/0.3 $\mathrm{ml}$ of sterile saline solution once, then subcutaneously injected with sterile saline solution $(0.5 \mathrm{ml}) 1 \mathrm{~h}$ later (D); iii) mice gastric intubation with $0.3 \mathrm{ml}$ sterile saline solution once, then subcutaneously injected with indomethacin (10 mg/kg BW) $1 \mathrm{~h}$ later (IN); iv) mice gastric intubation with $12 \mathrm{mg}$ DMG-Na/0.3 ml sterile saline solution once, then subcutaneously injected with indomethacin (10 mg/kg BW) $1 \mathrm{~h}$ later (DIN); and v) mice subcutaneously injected with indomethacin $(10 \mathrm{mg} / \mathrm{kg} \mathrm{BW})$, then gastrically intubated with $12 \mathrm{mg}$ DMG-Na/0.3 ml sterile saline solution
\end{abstract}

Correspondence to: Professor Tian Wang, College of Animal Science and Technology, Nanjing Agricultural University, 1 Weigang Tongwei Road, Nanjing, Jiangsu 210095, P.R. China

E-mail: tianwangnjau@163.com

Abbreviations: DMG-Na, dimethylglycine sodium salt; BW, body weight; ROS, reactive oxygen species; L, villus length; W, villus width; SOD, superoxide dismutase; GSH-Px, glutathione peroxidase; GSH, glutathione; GR, glutathione reductase; MnSOD, manganese superoxide dismutase; GPx, glutathione peroxidase; $\gamma$-GCL, $\gamma$-Glutamylcysteine ligase; MDA, malondialdehyde; PC, protein carbonyls; 8-OHdG, 8-hydroxy-2-deoxyguanosine; MMP, mitochondrial membrane potential; ATP, adenosine triphosphate; mtDNA, mitochondria DNA

Key words: dimethylglycine sodium salt, mice, small intestine, oxidative damage, mitochondrial dysfunction once after $1 \mathrm{~h}$ (IND). The present study was evaluated the effects of DMG-Na on mice intestinal damage induced by indomethacin injection. The histological morphology of the small intestine improved $(\mathrm{P}<0.05)$ in the DIN and IND groups, compared with the IN group. The antioxidant system was enhanced, oxidative damage was reduced, and the expression of antioxidant-associated genes was increased in the small intestine and its mitochondria in the DIN and IND groups, compared with the IN group. The above results suggested that pretreatment and treatment with DMG-Na reduced oxidative damage by enhancing antioxidant capacity, increasing the expression of antioxidant-associated genes, ameliorating mitochondrial dysfunction and suppressing apoptosis. Further study is required to determine the specific mechanism by which pretreatment and treatment with DMG-Na reduced small intestinal damage.

\section{Introduction}

It is well-known that the small intestine is the first organ to be affected when oxidative damage occurs, and acute small intestinal damage has an adverse effect on the overall health of animals. Oxidative damage is caused by an imbalance between the antioxidant system and the generation of free radicals, resulting in an increase in the level of reactive oxygen species (ROS), which mediate tissue damage and cause the release of inflammatory cytokines $(1,2)$. Mitochondria generate adenosine triphosphate (ATP) by respiration, which is accompanied by the synthesis of ROS, thus making them sensitive to oxidative damage. The excessive generation of ROS results in an imbalanced redox cell state, leading to a decrease in the mitochondrial membrane potential and disruption of mitochondrial function (3). It has been reported that subcutaneous injection of indomethacin in mice results in serious mucosal damage to the gastrointestinal tract, and this was used as the basis for a study on the clinical risks of small intestine failure due to damage (4).

Dimethylglycine (DMG) improves the body's immune system and relieves oxidative damage by scavenging excess free radicals (5). A previous study showed that DMG is a small water-soluble lipophilic molecule that effectively enters the body via the cell membrane and is absorbed by the intestinal 
cells, which improves the utilization of oral DMG (6). In addition, DMG may increase digestive enzyme capacity and enhance the ability of the intestinal brush border to come into contact with nutrients, subsequently promoting the digestion and absorption of nutrients in the small intestine (7). The biological consumption of choline is reduced in the metabolic pathway, suggesting DMG, as a methyl donor, is rapidly digested and absorbed, resulting in the body needing more ATP and inevitably increasing the generation of ROS (7). It has been reported that DMG-Na is similar to choline and betaine, and improves antioxidant capacity by acting as an important raw material for the glutathione synthesis pathway (8). A previous study indicated that DMG relieves oxidative damage and improves an animal's health and growth performance (9). Our previous results also suggested that DMG-Na protects against LPS-induced oxidative stress by increasing free radical scavenging capacity and antioxidant system activity (10). The present study was designed to study the effects of DMG-Na on oxidative damage and mitochondrial dysfunction in the small intestines of mice.

\section{Materials and methods}

Reagents and animals. Indomethacin (IN) was obtained from Sigma-Aldrich (Merck KGaA, Darmstadt, Germany). DMG-Na was obtained from Qilu Shenghua Pharmaceutical Co. Ltd. (Shandong, China). All other chemicals were commercially available and of reagent grade. Male Kunming mice $(\mathrm{n}=100 ; 40$ days old) with a body weight (BW) of 20-25 $\mathrm{g}$ were obtained from the Animal Multiplication Centre of Qinglong Mountain (Nanjing, China) (11-13) and raised for 4 weeks. Mice were raised under controlled conditions at $25 \pm 3^{\circ} \mathrm{C}, 60 \pm 10 \%$ humidity, and a 12/12 h light-dark cycle. All mice were fed common basal diets for 14 days. They had access to water and food ad libitum. On day 29, mice were randomly assigned to five groups ( $\mathrm{n}=20$ per group): i) Mice gastric intubation with $0.3 \mathrm{ml}$ sterile saline solution (once), then subcutaneously injected with sterile saline solution $(0.5 \mathrm{ml})$ after $1 \mathrm{~h}(\mathrm{CON})$; ii) mice gastric intubation with $12 \mathrm{mg}$ DMG-Na/ $/ .3 \mathrm{ml}$ of sterile saline solution once (10), then subcutaneously injected with sterile saline solution $(0.5 \mathrm{ml}) 1 \mathrm{~h}$ later (D); iii) mice gastric intubation with $0.3 \mathrm{ml}$ sterile saline solution once, then subcutaneously injected with indomethacin (10 mg/kg BW) $1 \mathrm{~h}$ later (IN) (4); iv) mice gastric intubation with $12 \mathrm{mg}$ DMG-Na/0.3 ml sterile saline solution once, then subcutaneously injected with indomethacin $(10 \mathrm{mg} / \mathrm{kg} \mathrm{BW}) 1 \mathrm{~h}$ later (DIN); and v) mice subcutaneously injected with indomethacin $(10 \mathrm{mg} / \mathrm{kg} \mathrm{BW})$, then gastrically intubated with $12 \mathrm{mg}$ DMG-Na/0.3 ml sterile saline solution once after $1 \mathrm{~h}$ (IND). Previous studies found that gastric intubation in mice with $12 \mathrm{mg}$ DMG-Na/ $/ 0.3 \mathrm{ml}$ sterile saline solution is beneficial to mice performance, including growth and antioxidant capacity (10). This study was approved and conducted under the supervision of Animal Care and Use Committee of Nanjing Agriculture University (Nanjing, China; approval no. SYXK 2017-0007). The health of each mouse was monitored every $6 \mathrm{~h}$ and humane endpoints were strictly adhered to, to determine when mice should be euthanized. All the mice were euthanized by intraperitoneal injection of $100 \mathrm{mg} / \mathrm{kg} \mathrm{BW}$ pentobarbital (Sigma-Aldrich; Merck KGaA) and death was confirmed by limb paralysis or if mice were unable to right themselves in $15 \mathrm{sec}$ when placed on their side. Following sacrifice, blood $(0.3 \mathrm{ml})$ and the small intestines were collected.

Histological study. Small intestine (jejunum and ileum) samples were fixed in $4 \%$ buffered formaldehyde and dehydrated using a graded series of xylene and ethanol, following which they were embedded in paraffin for histological analysis. The small intestine samples $(5 \mathrm{~mm})$ were subsequently deparaffinized using xylene and rehydrated with graded dilutions of ethanol. In total, ten slides for each sample were obtained and images were acquired using an optical binocular microscope (x400). The villus length (L), crypt depth, villus width (W), muscle thickness, and mucosa thickness were measured. The villus area was calculated using the following formula (14):

$$
\text { Villus area }=\pi \times\left(\frac{W}{2}\right) \sqrt{\left(\frac{W}{2}\right)^{2}+L^{2}}
$$

Antioxidant enzymes assays. Mouse small intestine $(1 \mathrm{~g}$; jejunum and ileum) was homogenized at $6,800 \mathrm{x} \mathrm{g}$ for $10 \mathrm{sec}$ in $9 \mathrm{ml} 0.9 \%$ sodium chloride solution on ice. The homogenate was centrifuged at $3,500 \mathrm{xg}$ for $15 \mathrm{~min}$ at $4^{\circ} \mathrm{C}$. The supernatant and serum were each used to measure the activity of superoxide dismutase (SOD; cat. no. A001), glutathione peroxidase (GSH-Px; cat. no. A005), glutathione (GSH1; cat. no. A006), and glutathione reductase (GR; cat. no. A062) according to the methods described by Panchenko et al (15) and Lawrence and Burk (16) using commercial diagnostic kits, as per the respective protocols provided by the manufacturer (Nanjing Jiancheng Bioengineering Institute, Nanjing, China).

Isolation of mice small intestine mitochondria and its antioxidant enzyme assays. Mitochondria from the small intestines of mice were isolated according to the method described by Roediger and Truelove (17) with a mitochondria isolation kit (cat. no. MITOISO2-1KT; Sigma-Aldrich; Merck KGaA). The mitochondria were lysed and the protein content was determined using the Micro Bicinchoninic Acid (BCA) protein assay kit (Nanjing Jiancheng Institute of Bioengineering). The levels of manganese superoxide dismutase (MnSOD; cat. no. A001-2), glutathione peroxidase (GPx; cat. no. A005), glutathione (GSH2; cat. no. A006), GR (cat. no. A062) and $\gamma$-glutamylcysteine ligase ( $\gamma$-GCL; cat. no. A120) in the small intestinal mitochondria were determined according to the methods described by Langston et al (18), Van et al (19) and Lawrence and Burk (16). All assays were conducted in triplicate according to the protocols provided by the manufacturer (Nanjing Jiancheng Bioengineering Institute).

Lipid peroxidation, protein oxidation and 8-hydroxy-2'deoxyguanosine assays. Lipid peroxidation, expressed as malondialdehyde concentration, was determined according to the methods of Botsoglou et al (20). With a malondialdehyde (MDA; cat. no. A003) assay kit (Nanjing Jiancheng Bioengineering Institute). Protein oxidation in mouse small intestinal mitochondria was calculated as the concentration of the protein carbonyls using a spectrophotometer, which was measured as previously described (21) and was expressed as 
$\mathrm{nmol} / \mathrm{mg}$ protein. The content of 8-hydroxy-2'-deoxyguanosine $(8-\mathrm{OHdG})$ in mitochondria from the small intestines of mice was measured using an ELISA kit (cat. no. H165; Nanjing Jiancheng Bioengineering Institute) according to the manufacturer's instructions, and was expressed as $\mathrm{ng} / \mathrm{mg}$ protein.

Mitochondrial ROS and mitochondrial membrane potential (MMP) assays. The concentration of ROS in mouse small intestinal mitochondria was determined using a previously described method (22) and a ROS assay kit (cat. no. E004; Nanjing Jiancheng Bioengineering Institute). Alterations in the MMP in were detected according to a previously described method (23) using a MMP assay kit (cat. no. G009; Nanjing Jiancheng Bioengineering Institute).

Cell apoptosis, ATP concentration and mitochondrial (mt)DNA copy number assays. The number of apoptotic and necrotic cells was measured according to a previously described method (24). An Alexa Fluor ${ }^{\circledR} 488$ Annexin V/Dead Cell Apoptosis kit (Thermo Fisher Scientific, Inc., Waltham, MA, USA) was used. The concentration of cellular adenosine triphosphate (ATP) in mouse small intestines was determined according to the method described by Liu et al (25). The mtDNA copy number in the small intestine of mice was determined using a real-time fluorescence quantitative polymerase chain reaction (PCR) kit (Tli RNaseH Plus; Takara Bio, Inc., Otsu, Japan) (26). In brief, $20 \mu \mathrm{l}$ PCR mixture consisting of $10 \mu \mathrm{l}$ SYBR Premix Ex Taq (2X), $0.4 \mu \mathrm{l}$ upstream primer, $0.4 \mu 1$ downstream primer, $0.4 \mu 1$ ROX dye (50X), $6.8 \mu 1$ ultrapure water, and $2 \mu \mathrm{l} \mathrm{cDNA}$ template was used. The sequence of the $M t_{D \text {-loop }}$ gene upstream primer was 5'-AGGACTACGGCT TGAAAAGC-3', and the sequence of the downstream primer was 5'-CATCTTGGCATCTTCAGTGCC-3'; the length of the target fragment was $198 \mathrm{bp}$. The sequence of the $\beta$-actin upstream primer was 5'-TTCTTGGGTATGGAGTCCTG-3' and that of the downstream primer was 5'-TAGAAGCATTTG CGGTGG-3'; the length of the target fragment was $150 \mathrm{bp}$. The amplification for each mouse small intestine sample was performed in triplicate. The fold-expression of each gene was calculated according to the $2^{-\Delta \Delta \mathrm{Cq}}$ method (27), in which $\beta$-actin was used as an internal standard.

Reverse transcription-quantitative polymerase chain reaction $(R T-q P C R)$. Total RNA extracted from mouse small intestines using TRIzol ${ }^{\circledR}$ reagent (Thermo Fisher Scientific, Inc., Waltham, MA, USA), and was reverse-transcribed using a Perfect Real Time, SYBR PrimeScript RT-PCR kit (Takara Bio, Inc.) according to manufacturer's instructions. The mRNA expression levels of specific genes were quantified by PCR, using a SYBR Premix Ex Taq II (Tli RNaseH Plus; Takara Bio, Inc.) in an ABI 7300 Fast Real-Time PCR detection system (Applied Biosystems; Thermo Fisher Scientific, Inc.), according to manufacturer's instructions. The SYBR-Green PCR mixture consisted of $10 \mu \mathrm{l} \mathrm{SYBR}$ Premix Ex Taq (2X), $0.4 \mu 1$ each of the forward and reverse primers,

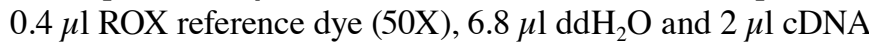
template. The amplification for each mouse small intestine was performed in triplicate, and the fold-expression of each gene was calculated according to the $2^{-\Delta \Delta \mathrm{Cq}}$ method (27), in which $\beta$-actin was used as an internal standard. The primer sequences used are provided in Table I.

Western blotting assay. Antibodies against $\alpha$-tubulin, nuclear factor erythroid 2-related factor 2 (Nrf2), heme oxygenase 1 (HO1), and sirtuin 1 (Sirt1) were purchased from Cell Signaling Technology, Inc. (Danvers, MA, USA). Samples were lysed using Laemmli sample buffer [2\% SDS, $62 \mathrm{mM}$ Tris, $10 \%$ glycerol, $5 \% \beta$-mercaptoethanol, $0.005 \%$ bromphenol blue ( $\mathrm{pH}$ 6.8)]. The protein content of the sample was assayed using the BCA Protein Assay kit (Beyotime Institute of Biotechnology, Haimen, China). For western blot analysis, $50 \mathrm{mg}$ protein from each sample was subjected to SDS-PAGE (10\% gel) and transferred to polyvinylidene difluoride membranes. The membranes were blocked in 5\% non-fat dry milk for $12 \mathrm{~h}$ at $4^{\circ} \mathrm{C}$, followed by incubation with antibodies against Nrf2 (cat. no. 12721; 1:1,000), HO1 (cat. no. 82206; 1:1,000), Sirt1 (cat. no. 9475; 1:1,000) and $\alpha$-tubulin (cat. no. $2125 ; 1: 1,000$ ) for $10 \mathrm{~h}$ at $4^{\circ} \mathrm{C}$. Next, membranes were incubated with goat-anti-rabbit secondary antibody $(1: 1,000$; Cell Signaling Technology, Inc.) for $2 \mathrm{~h}$ at $4^{\circ} \mathrm{C}$. Bands were visualized using enhanced chemiluminescence reagents (ECL-Kit; Beyotime Institute of Biotechnology,) followed by autoradiography. Images of the membranes were taken using a Luminescent Image Analyzer-4000 system (Fujifilm, Tokyo, Japan) and quantified using ImageJ 1.42 q software (National Institutes of Health, Bethesda, MD, USA).

Statistical analysis. Data are presented as the mean \pm standard error of the mean of three experimental repeats, and were analyzed by one-way analysis in Statistical Analysis System software (version 9.1; SAS Institute, Inc., Cary, NC, USA). This was followed by the Tukey's test, when significant differences were found. $\mathrm{P}<0.05$ was considered to indicate a statistically significant difference.

\section{Results}

Histological study. Histological analysis revealed that the villus length, crypt depth, villus width, muscle thickness, mucosa thickness, and villus area values of the small intestine (jejunum and ileum) were lower $(\mathrm{P}<0.05)$ in the IN group, compared to the CON group (Figs. 1 and 2). However, compared with mice in the IN group, histological analysis showed that the L, crypt depth, W, muscle thickness, mucosa thickness, and villus area values of the small intestine were higher $(\mathrm{P}<0.05)$ in the DIN and IND groups (Figs. 1 and 2$)$. There was no significant difference between the DIN and IND group in the histological analysis. The results indicated that DMG-Na could prevent damage to the small intestine.

Antioxidant enzymes assays. The effects of DMG-Na on serum and small intestinal antioxidant capacity, including SOD, GSH-Px, GSH1, GR and MDA are shown in Figs. 3 and 4. The IN group had lower activity levels $(\mathrm{P}<0.05)$ of antioxidant enzymes and a higher $(\mathrm{P}<0.05)$ concentration of MDA in both serum and the small intestine, compared with the CON group. However, the DIN and IND groups had higher activity levels $(\mathrm{P}<0.05)$ of antioxidant enzymes and a lower $(\mathrm{P}<0.05) \mathrm{MDA}$ concentration in serum and the small intestine, compared with 
Table I. Primer sequences used for the reverse transcription-quantitative polymerase chain reaction assay.

\begin{tabular}{|c|c|c|c|}
\hline Gene name & Direction & Sequence $\left(5^{\prime}-3^{\prime}\right)$ & GenBank accession number \\
\hline \multirow[t]{2}{*}{$\beta$-actin } & $\mathrm{F}$ & CTGTCCCTGTATGCCTCTG & NM_007393.3 \\
\hline & $\mathrm{R}$ & ATGTCACGCACGATTTCC & \\
\hline \multirow[t]{2}{*}{$N r f 2$} & $\mathrm{~F}$ & GATGTCACCCTGCCCTTAG & NM_205117.1 \\
\hline & $\mathrm{R}$ & CTGCCACCATGTTATTCC & \\
\hline \multirow[t]{2}{*}{ HOl } & $\mathrm{F}$ & GGTCCCGAATGAATGCCCTTG & HM237181.1 \\
\hline & $\mathrm{R}$ & ACCGTTCTCCTGGCTCTTGG & \\
\hline \multirow[t]{2}{*}{$C u / Z n S O D$} & $\mathrm{~F}$ & CCGGCTTGTCTGATGGAGAT & NM_205064.1 \\
\hline & $\mathrm{R}$ & TGCATCTTTTGGTCCACCGT & \\
\hline \multirow[t]{2}{*}{$G S H-P x$} & $\mathrm{~F}$ & GACCAACCCGCAGTACATCA & NM_001277853.1 \\
\hline & $\mathrm{R}$ & GAGGTGCGGGCTTTCCTTTA & \\
\hline \multirow[t]{2}{*}{$M n S O D$} & $\mathrm{~F}$ & AGGAGGGGAGCCTAAAGGAGA & NM_204211.1 \\
\hline & $\mathrm{R}$ & CCAGCAATGGAATGAGACCTG & \\
\hline \multirow[t]{2}{*}{ Sirt1 } & $\mathrm{F}$ & TGCAGACGTGGTAATGTCCAAAC & NM_019812.2 \\
\hline & $\mathrm{R}$ & ACATCTTGGCAGTATTTGTGGTGAA & \\
\hline \multirow[t]{2}{*}{$\gamma-G C L c$} & $\mathrm{~F}$ & TGCGGTTCTGCACAAAATGG & XM_419910.3 \\
\hline & $\mathrm{R}$ & TGCTGTGCGATGAATTCCCT & \\
\hline \multirow{2}{*}{$\gamma-G C L m$} & $\mathrm{~F}$ & CCAGAACGTCAAAGCACACG & NM_001007953.1 \\
\hline & $\mathrm{R}$ & TCСТCССАTСССCCAGAAAT & \\
\hline \multirow[t]{2}{*}{$\operatorname{Tr} x 2$} & $\mathrm{~F}$ & AGTACGAGGTGTCAGCAGTG & NM_001031410.1 \\
\hline & $\mathrm{R}$ & CACACGTTGTGAGCAGGAAG & \\
\hline \multirow[t]{2}{*}{$\operatorname{Tr} x-R 2$} & $\mathrm{~F}$ & CCGGGTCCCTGACATCAAA & NM_001122691.1 \\
\hline & $\mathrm{R}$ & TAGCTTCGCTGGCATCAACA & \\
\hline \multirow[t]{2}{*}{$\operatorname{Prx3}$} & $\mathrm{F}$ & ACCTCGTGCTCTTCTTCTACC & XM_004942320.1 \\
\hline & $\mathrm{R}$ & ACCACCTCGCAGTTCACATC & \\
\hline \multirow[t]{2}{*}{$O C L N$} & $\mathrm{~F}$ & CCGTAACCCCGAGTTGGAT & NM_205128.1 \\
\hline & $\mathrm{R}$ & ATTGAGGCGGTCGTTGATG & \\
\hline \multirow[t]{2}{*}{$C L D N 2$} & $\mathrm{~F}$ & ССTGCTCACCCTCATTGGAG & NM_001277622.1 \\
\hline & $\mathrm{R}$ & GCTGAACTCACTCTTGGGCT & \\
\hline \multirow[t]{2}{*}{$C L D N 3$} & $\mathrm{~F}$ & CCCGTCCCGTTGTTGTTTTG & NM_204202.1 \\
\hline & $\mathrm{R}$ & ССССТТСААССТТСССGААА & \\
\hline \multirow[t]{2}{*}{$\mathrm{ZO1}$} & $\mathrm{F}$ & TGTAGCCACAGCAAGAGGTG & XM_413773.4 \\
\hline & $\mathrm{R}$ & CTGGAATGGCTCCTTGTGGT & \\
\hline
\end{tabular}

F, forward; R, reverse; $N r f 2$, nuclear factor erythroid 2-related factor 2; $H O 1$, heme oxygenase 1; $C u / Z n S O D$, copper and zinc superoxide dismutase; GSH-Px, glutathione peroxidase; $M n S O D$, manganese superoxide dismutase; Sirt 1, sirtuin 1; $\gamma$-GCLc, $\gamma$-glutamylcysteine ligase c; $\gamma$-GCLm, $\gamma$-glutamylcysteine ligase $\mathrm{m}$; $\operatorname{Tr} x 2$, thioredoxin 2; $\operatorname{Tr} x-R 2$, thioredoxin reductase 2; $\operatorname{Pr} x 3$, peroxiredoxin 3; OCLN, occludin; $C L D N$, claudin; $Z O 1$, zonula occludens- 1 .

the IN group. There was no significant difference between DIN and IND groups on the antioxidant enzymes activity of mice small intestine. The results suggested that DMG-Na could improve antioxidant capacity, thus to relieve the oxidative damage in small intestine.

Small intestine mitochondrial antioxidant enzyme assays. The IN group had lower $(\mathrm{P}<0.05)$ levels of MnSOD, GPx, GSH2, GR and $\gamma$-GCL in mitochondria from the small intestine, compared with the CON group (Fig. 5). The DIN and IND groups, however, had higher $(\mathrm{P}<0.05)$ levels of MnSOD, GPx, GSH2, GR, and $\gamma$-GCL in small intestinal mitochondria, compared with the IN group. There was no significant difference between DIN and IND groups. The results showed that DMG-Na could suppress the oxidative damage via enhancing mitochondrial antioxidant capacity in small intestine.

Oxidative damage assays. Higher $(\mathrm{P}<0.05)$ levels of ROS, $\mathrm{PC}, 8-\mathrm{OHdG}$, apoptosis, and necrosis, as well as a higher ATP/mitochondrial DNA (mtDNA) ratio and lower $(\mathrm{P}<0.05)$ levels of MMP, ATP and mtDNA were observed in the IN group, compared with the CON group (Fig. 6). The opposite effects were observed in the DIN and IND groups, compared with the IN group $(\mathrm{P}<0.05$; Fig. 6). There was no significant difference between DIN and IND groups. In the present study, DMG-Na could relieve the oxidative damage possibly due to the increasing of antioxidant capacity in small intestine. 
$\begin{array}{llll}\text { CON D } & \text { IN }\end{array}$

Jejunum

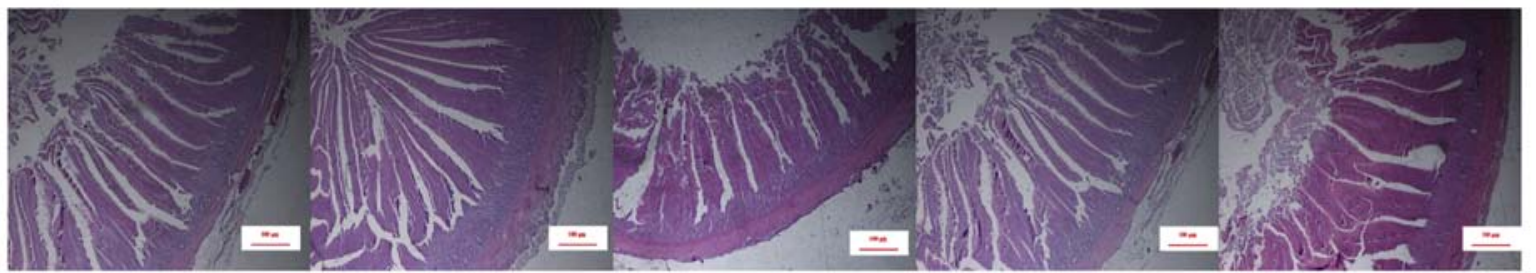

Ileum

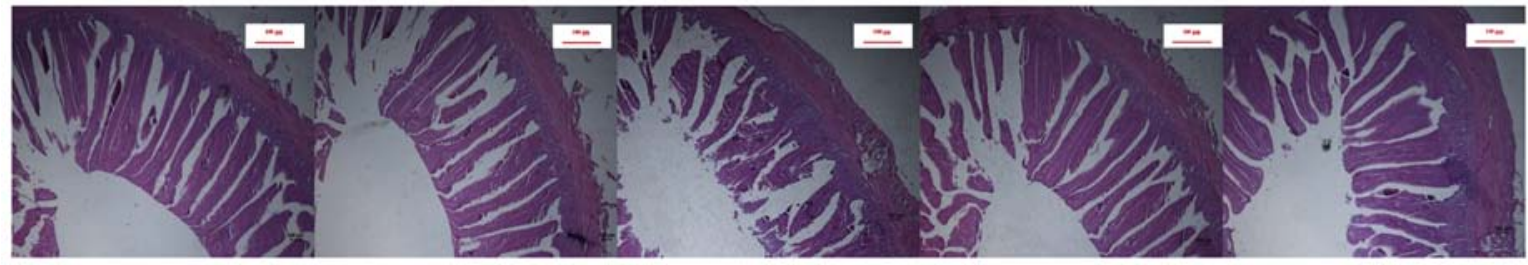

Figure 1. Hematoxylin and eosin staining of the jejunum and ileum. Scale bar, $100 \mu \mathrm{m}$. DMG-Na, dimethylglycine sodium salt; CON, intubation and injection with saline; D, intubation with DMG-Na and injection with saline; IN, intubation with saline and injection with indomethacin; DIN, intubation with DMG-Na and injection with indomethacin; IND, injection with indomethacin and intubation with DMG-Na.
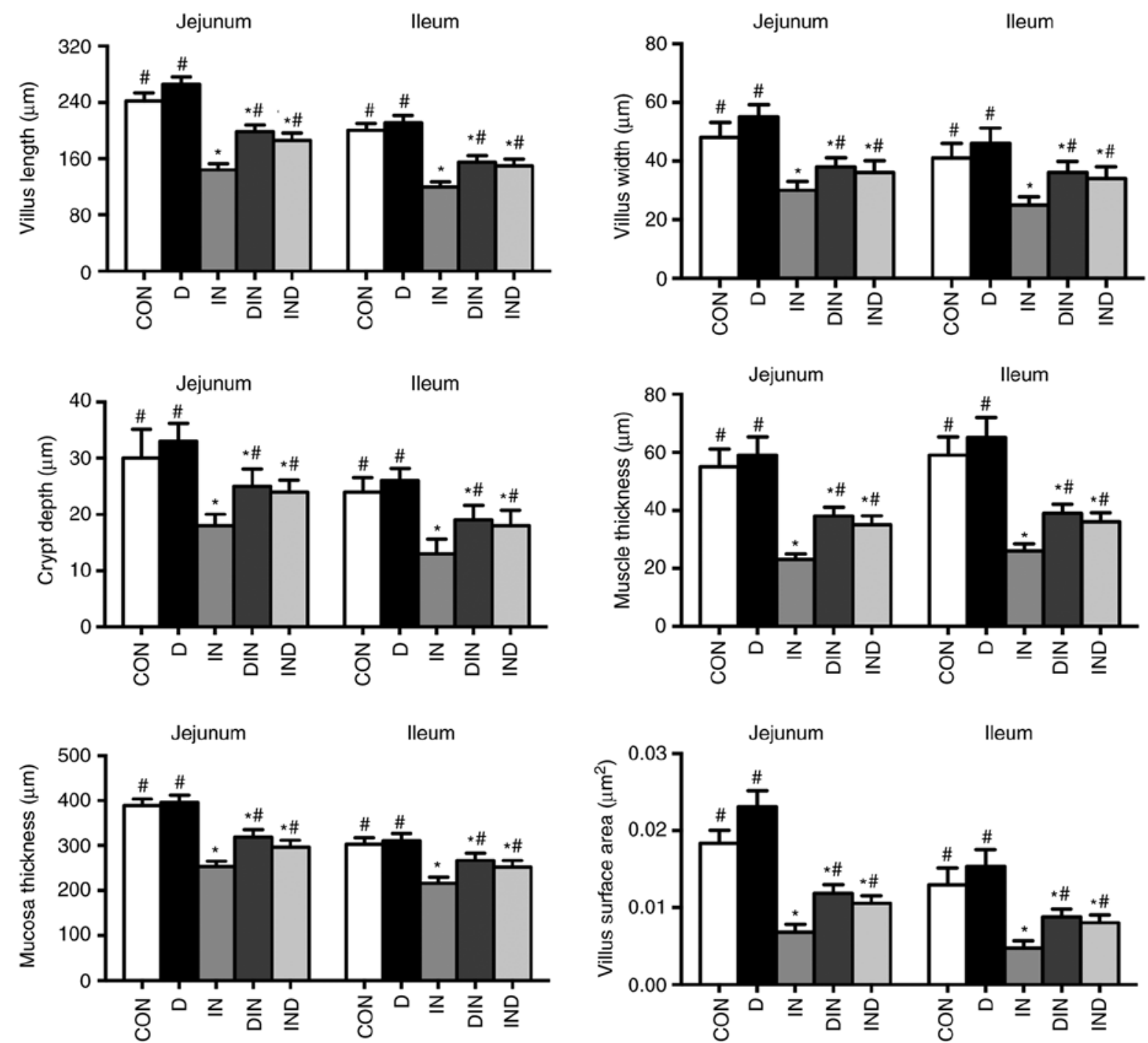

Figure 2. Effects of DMG-Na on small intestine histological morphology in IN-injected mice. Data are expressed as the mean \pm standard error of the mean $(\mathrm{n}=20)$. ${ }^{\mathrm{P}} \mathrm{P}<0.05$ vs. CON; ${ }^{\text {"P }} \mathrm{P}<0.05$ vs. IN. DMG-Na, dimethylglycine sodium salt; CON, intubation and injection with saline; D, intubation with DMG-Na and injection with saline; IN, intubation with saline and injection with indomethacin; DIN, intubation with DMG-Na and injection with indomethacin; IND, injection with indomethacin and intubation with DMG-Na. 

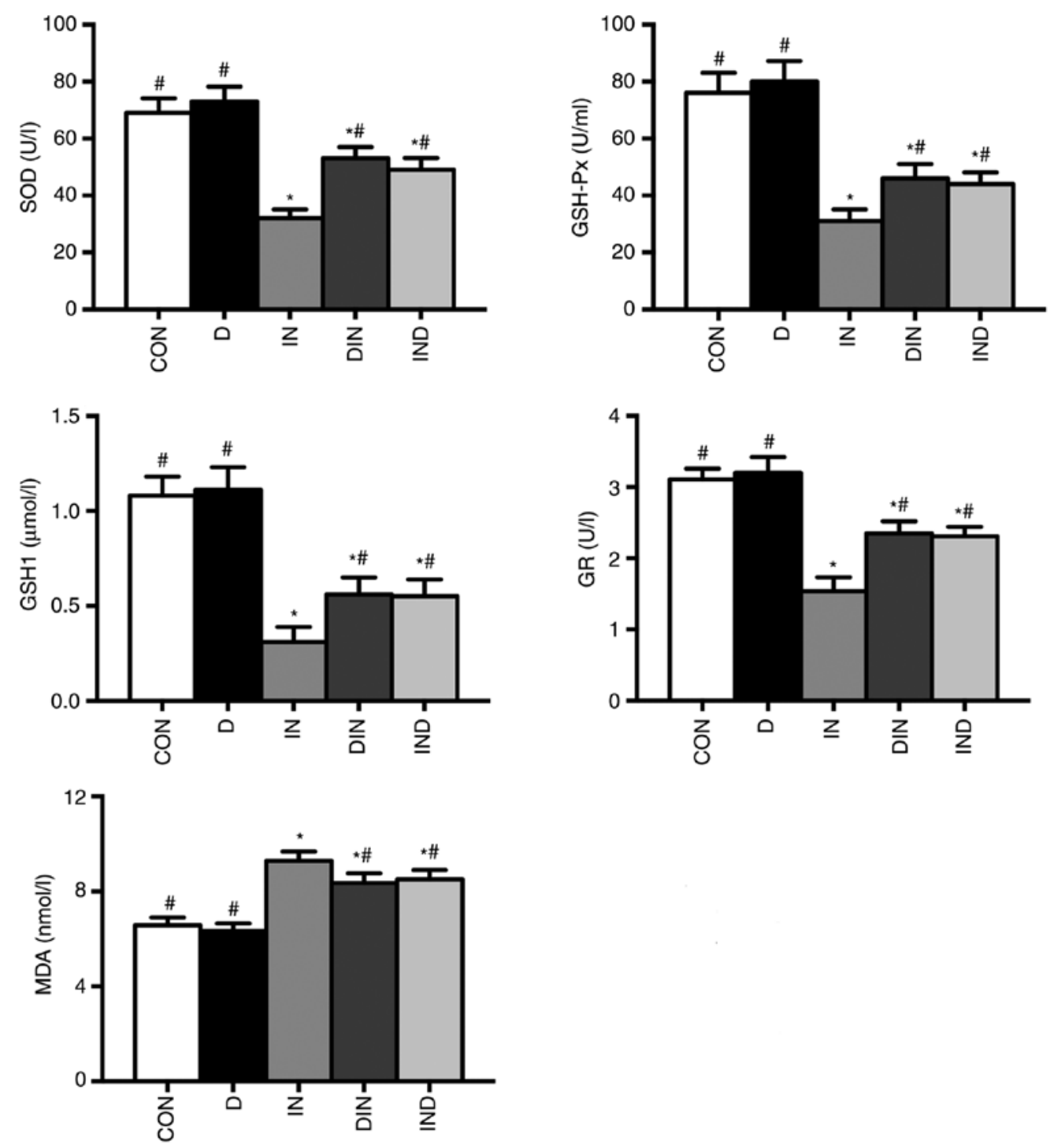

Figure 3. Effects of DMG-Na on serum antioxidant capacity in indomethacin-injected mice. Data are expressed as the mean \pm standard error of the mean $(\mathrm{n}=20)$. " $\mathrm{P}<0.05$ vs. CON; ${ }^{\mathrm{P}}<0.05$ vs. IN. DMG-Na, dimethylglycine sodium salt; SOD, superoxide dismutase; GSH-Px, glutathione peroxidase; GSH1, glutathione; GR, glutathione reductase; MDA, malondialdehyde; CON, intubation and injection with saline; D, intubation with DMG-Na and injection with saline; IN, intubation with saline and injection with indomethacin; DIN, intubation with DMG-Na and injection with indomethacin; IND, injection with indomethacin and intubation with DMG-Na.

Gene expression. The expression of antioxidant-associated genes in the small intestine (Nrf2, HO-1, CLDN2, CLDN3, $\mathrm{Cu} / \mathrm{ZnSOD}$, GSH-Px, Sirt1, $\gamma-G C L c, \gamma-G C L m, O C L N$ and $\mathrm{ZO1})$ and in the small intestinal mitochondria $(\operatorname{Tr} x 2, \operatorname{Tr} x-R 2$, Prx3 and $M n S O D)$ was lower $(\mathrm{P}<0.05)$ in the IN group, compared with the CON group (Fig. 7). Expression of the same antioxidant-associated genes in the small intestine and small intestinal mitochondria was higher $(\mathrm{P}<0.05)$ in the DIN and IND groups, compared with the IN group (Fig. 7). There was no significant difference between DIN group and IND groups.

Protein expression. The IN group had lower $(\mathrm{P}<0.05)$ Sirt1 and higher $(\mathrm{P}<0.05) \mathrm{Nrf} 2$ and HO-1 expression (Fig. 8), compared with the CON group. The DIN and IND groups had higher $(\mathrm{P}<0.05)$ Sirt1 expression accompanied by lower $(\mathrm{P}<0.05) \mathrm{Nrf} 2$ and HO-1 expression, compared with the IN group (Fig. 8). There was no significant difference between the DIN and IND groups. In the current study, DMG-Na could improve the antioxidant-related gene and protein level, which was consistent with the above results of antioxidant system, thus confirmed its used as an antioxidant to improve the oxidative damage in small intestine.

\section{Discussion}

The small intestine, which is the main organ involved in digestion and the absorption of nutrients, is the first line of defense to protect the body from oxidative damage induced by external pathogenic microorganisms and toxins (28). Substances depend on diffusion or active transport to cross cell membranes in the small intestine, and this movement is regulated by the structure of the cell-to-cell contacts (29). Thus, good intestinal morphology is crucial for maintaining health. It has previously been shown that DMG, which is a raw material for the synthesis of glutathione, is an important antioxidant required to simultaneously maintain the normal 

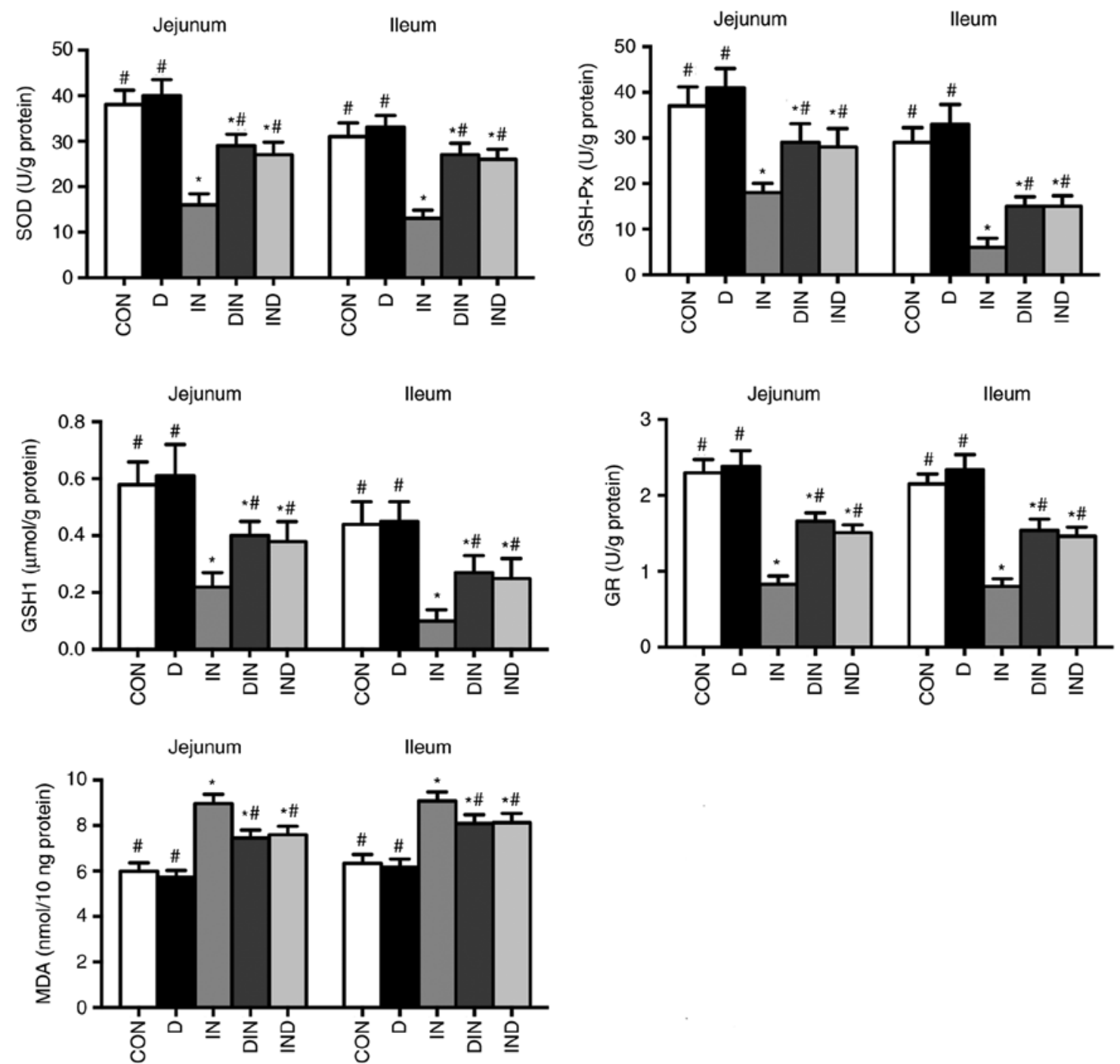

Figure 4. Effects of DMG-Na on small intestinal antioxidant capacity in indomethacin-injected mice. Data are expressed as the mean \pm standard error of the mean $(\mathrm{n}=20)$. "P<0.05 vs. CON; ${ }^{*} \mathrm{P}<0.05$ vs. IN. DMG-Na, dimethylglycine sodium salt; SOD, superoxide dismutase; GSH-Px, glutathione peroxidase; GSH1, glutathione; GR, glutathione reductase; MDA, malondialdehyde; CON, intubation and injection with saline; D, intubation with DMG-Na and injection with saline; IN, intubation with saline and injection with indomethacin; DIN, intubation with DMG-Na and injection with indomethacin; IND, injection with indomethacin and intubation with DMG-Na.

histological morphology of the small intestine and to protect the body from oxidative damage (8). The protective effect of DMG against oxidative damage to cells has also been shown in another study (30), and this may be one potential explanation for the better histological morphology of the small intestine in mice from the DMG-Na groups, compared with that in the IN groups. In the present study, DMG-Na administered to mice as a preventative measure or as a treatment for IN exposure, improved the histological morphology of the small intestine compared to that of mice given IN alone, suggesting that DMG-Na could prevent or reverse damage to the small intestine induced by the injected IN.

Oxidative damage increases the level of ROS, which decreases antioxidant capacity and disrupts the mitochondrial structure (31). The tissue damage can be improved by activity of the SOD enzyme in cells, which catalyzes the conversion of endogenous superoxide anions to hydrogen peroxide through disproportionation, which is finally neutralized by the intracellular GSH-Px enzyme (31). The mitochondrial antioxidant system is composed of enzymes and non-enzymatic antioxidants that protect the body from oxidative damage (32). It has been reported that the MnSOD enzyme and GSH-related metabolic enzymes are crucial for suppressing oxidative damage in mitochondria (33). The $\gamma$-GCL enzyme is an important rate-limiting enzyme in the synthesis of $\gamma$-glutamylcysteine that is crucial in relieving oxidative damage (18). Previous studies have demonstrated that DMG could act as an important additive to improve the body's antioxidant capacity $(8,10)$. In support of this, the present study reported that DMG-Na, given for prevention or as a treatment, reduced oxidative damage in the small intestines of mice by increasing their antioxidant capacity. It was speculated that DMG-Na may have improved antioxidant capacity by scavenging excess ROS, thereby maintaining the balance of the intracellular redox state.

In the oxidative damage model of the mouse small intestine, blockade of the oxidative phosphorylation reaction increased ROS levels (34). Excessive ROS generation damages biological macromolecules, such as membrane lipids and proteins, and 

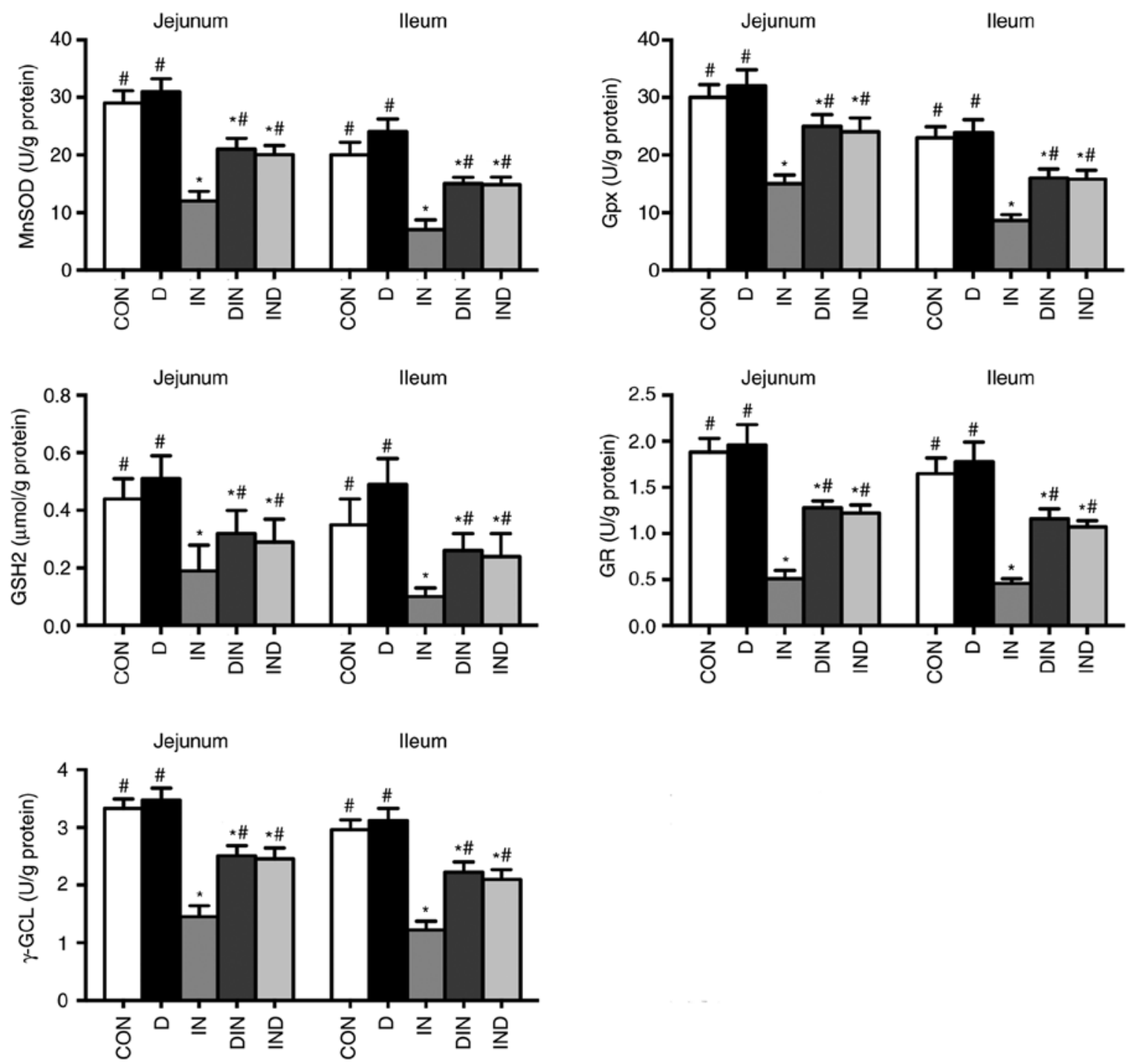

Figure 5. Effects of DMG-Na on small intestine mitochondrial antioxidant capacity in indomethacin-injected mice. Data are expressed as the mean \pm standard error of the mean $(n=20) .{ }^{~} \mathrm{P}<0.05$ vs. CON; ${ }^{\#} \mathrm{P}<0.05$ vs. IN. MnSOD, manganese superoxide dismutase; GPx, glutathione peroxidase; GSH2, glutathione; GR, glutathione reductase; $\gamma$-GCL, $\gamma$-glutamylcysteine ligase; DMG-Na, dimethylglycine sodium salt; SOD, superoxide dismutase; GSH-Px, glutathione peroxidase; GSH1, glutathione; GR, glutathione reductase; MDA, malondialdehyde; CON, intubation and injection with saline; D, intubation with DMG-Na and injection with saline; IN, intubation with saline and injection with indomethacin; DIN, intubation with DMG-Na and injection with indomethacin; IND, injection with indomethacin and intubation with DMG-Na.

exacerbates oxidative damage through lipid peroxidation and protein oxidation reactions (35). In conditions of oxidative damage, excessive ROS may destroy the structural integrity of the mitochondrial bilayer by damaging unsaturated fatty acids and structural proteins in the mitochondrial membrane (36). The present study showed that oxidative damage in the mouse small intestine resulted in a higher concentration of MDA, PC, 8-OHdG and ROS compared with control group mice. It has previously been shown that DMG, a natural antioxidant, effectively neutralizes free radicals to alleviate oxidative damage (5). Therefore, it was speculated that DMG-Na may inhibit lipid peroxidation and protein oxidation reactions by scavenging excess ROS.

The level of MMP, which is negatively associated with ROS concentration, is an indicator of mitochondria-dependent apoptosis. As the level of MMP decreases, mitochondrial oxidative phosphorylation becomes uncoupled, which results in an increase in ROS levels and excessive ATP consumption (32).
ATP is the product of the oxidative phosphorylation reaction associated with mitochondrial function (37), and it also acts as an important substrate for RNA synthesis (38). Mitochondria have their own mtDNA genome that is responsible for the synthesis and regulation of proteins required for mitochondrial function. Alterations in mtDNA copy number serve as indicators of mitochondrial dysfunction, which contributes to many diseases (39). Previous studies have reported that oxidative damage could decrease the mtDNA copy number and damage the mitochondrial DNA by altering the reductive environment of cells and mitochondria $(39,40)$. The present study also indicated that the lower level of apoptosis may be due to suppression by DMG-Na of oxidative damage, which verifies the results of previous studies that suggested natural antioxidants inhibit apoptosis by protecting cells from oxidative damage $(8,41)$. Furthermore, the present study showed that DMG-Na prevention and treatment reduced the effects of oxidative damage on MMP, ATP, mtDNA and apoptosis in 

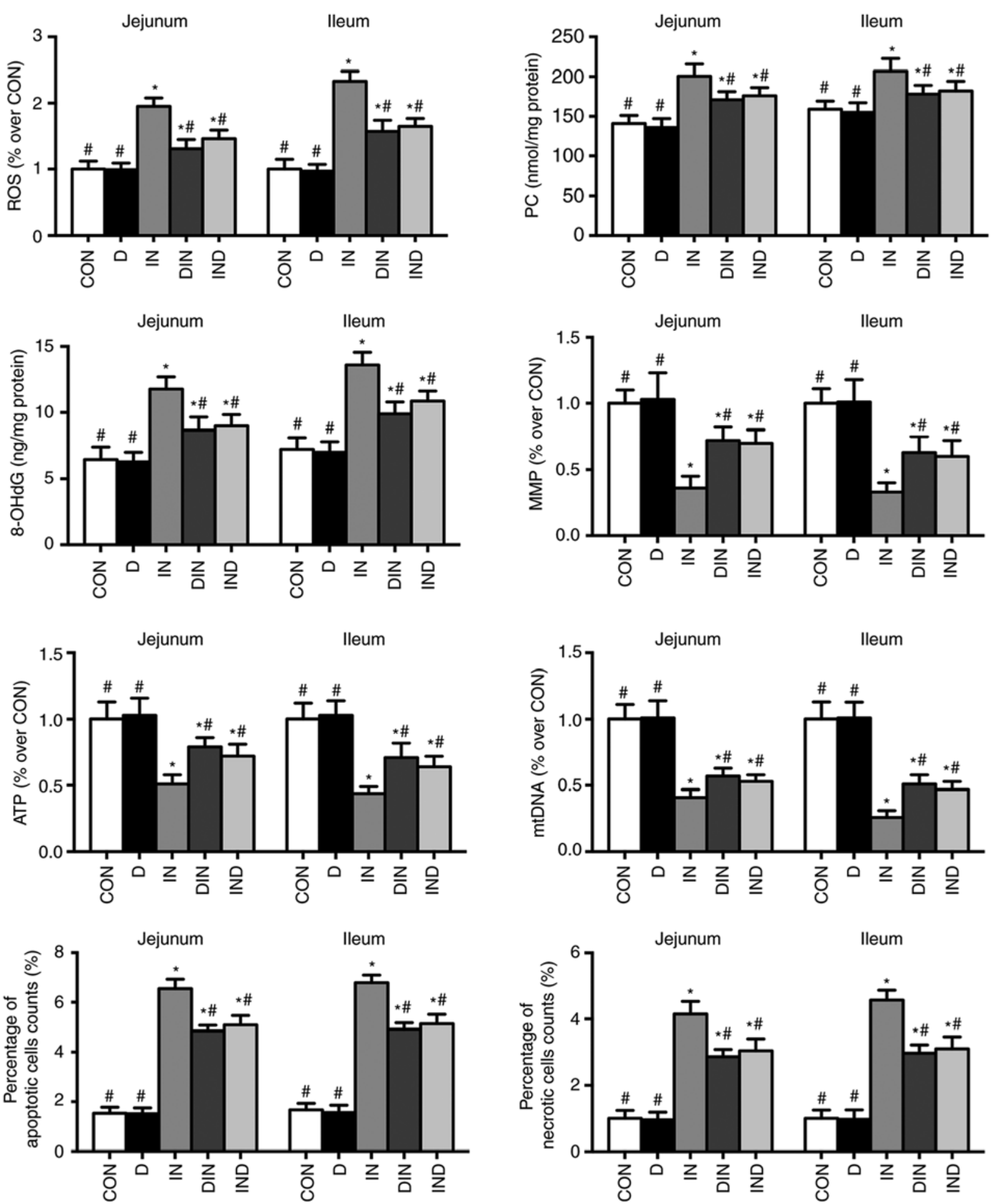

Figure 6. Effects of DMG-Na on small intestinal oxidative damage in indomethacin-injected mice. Data are expressed as the mean \pm standard error of the mean ( $\mathrm{n}=20$ ). " $\mathrm{P}<0.05$ vs. CON; ${ }^{\#} \mathrm{P}<0.05$ vs. IN. ROS, reactive oxygen species; PC, protein carbonyls; 8-OHdG, 8-hydroxy-2-deoxyguanosine; MMP, mitochondrial membrane potential; ATP, adenosine triphosphate; mtDNA, mitochondria DNA; DMG-Na, dimethylglycine sodium salt; CON, intubation and injection with saline; D, intubation with DMG-Na and injection with saline; IN, intubation with saline and injection with indomethacin; DIN, intubation with DMG-Na and injection with indomethacin; IND, injection with indomethacin and intubation with DMG-Na.

the small intestine of mice. Considering the current results, it was hypothesized that there was a correlation between the anti-apoptotic effect of DMG-Na and the protective effects of DMG-Na on mitochondrial function in the damaged small intestines of mice.

The present study demonstrated that DMG-Na increased the expression of antioxidant-associated genes in the mouse model of small intestinal damage. Activation of the Nrf2 (42), HOI (43) and SIRTI (44) genes is important in reducing oxidative damage, and also for regulating the expression of genes encoding antioxidant enzymes. The mitochondria are rich in $\operatorname{Tr} x 2$ (45), $\operatorname{Tr} x-R 2$ (46) and $\operatorname{Pr} x 3$ (46) that compose a unique antioxidant system to relieve oxidative damage by scavenging free radicals and regulating the mitochondria-dependent 

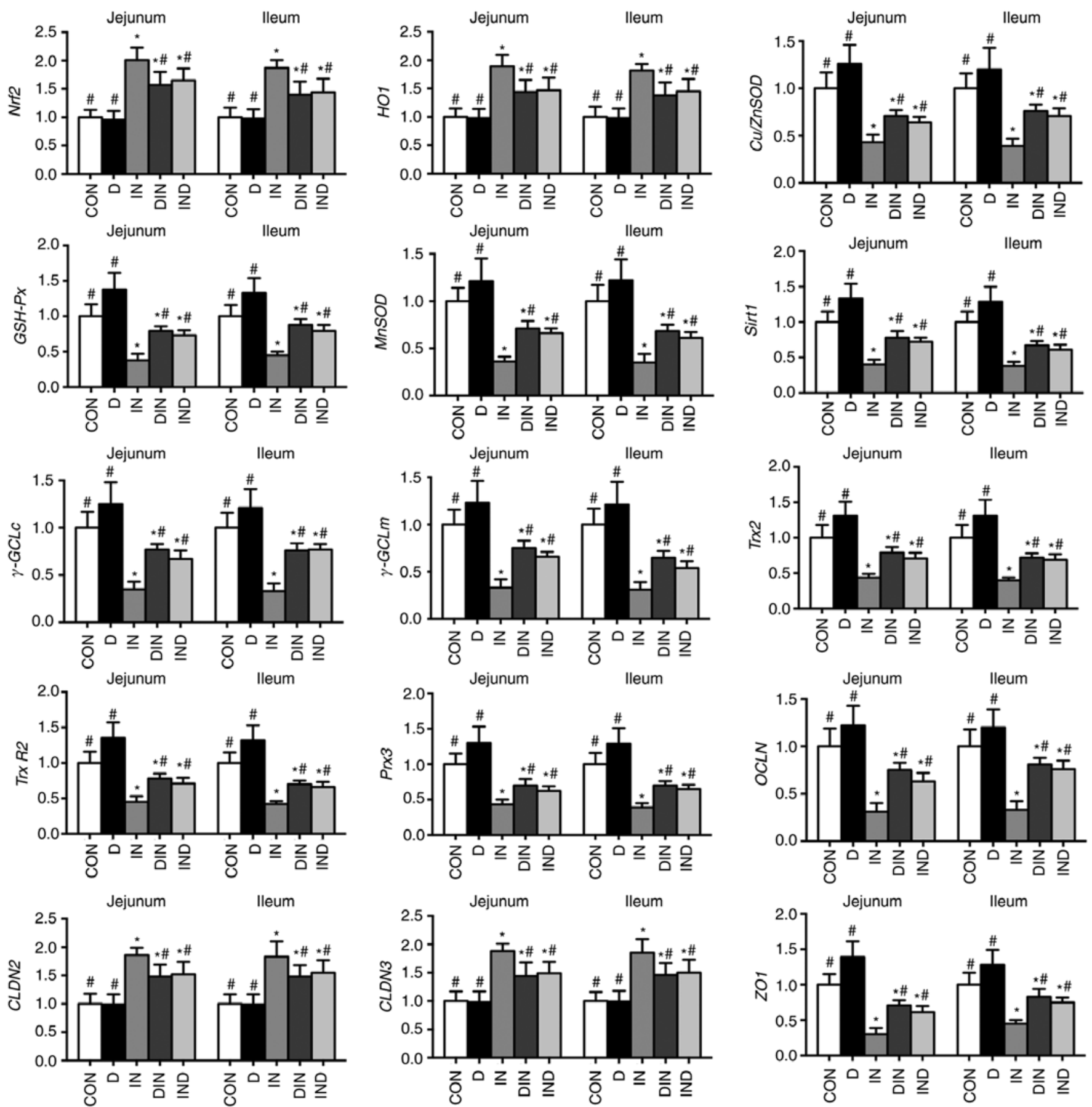

Figure 7. Effects of DMG-Na on small intestine gene expression in indomethacin-injected mice. Data are expressed as the mean \pm standard error of the mean $(\mathrm{n}=20)$. ${ }^{*} \mathrm{P}<0.05$ vs. $\mathrm{CON} ;{ }^{*} \mathrm{P}<0.05$ vs. IN. Nrf2, nuclear factor erythroid 2-related factor $2 ; \mathrm{HOl}$, heme oxygenase $1 ; \mathrm{Cu} / \mathrm{ZnSOD}$, copper and zinc superoxide dismutase; GSH-Px, glutathione peroxidase; MnSOD, manganese superoxide dismutase; Sirt1, sirtuin 1; $\gamma$-GCLc; $\gamma$-glutamylcysteine ligase c; $\gamma$-GCLm, $\gamma$-glutamylcysteine ligase $\mathrm{m} ; \operatorname{Tr} x 2$, thioredoxin 2; $\operatorname{Tr} x-R 2$, thioredoxin reductase 2; $\operatorname{Pr} x 3$, peroxiredoxin 3; $O C L N$, occluding; $C L D N$, claudin; ZOI, zonula occludens-1; DMG-Na, dimethylglycine sodium salt; CON, intubation and injection with saline; D, intubation with DMG-Na and injection with saline; IN, intubation with saline and injection with indomethacin; DIN, intubation with DMG-Na and injection with indomethacin; IND, injection with indomethacin and intubation with DMG-Na.

apoptotic pathways (47). It has been indicated that the gene $\mathrm{ZOI}$ is correlated with paracellular permeability. Furthermore, together with the genes $O C L N$ and $C L D N(48)$ from the same gene family, it is a key regulator of intestinal permeability, which indirectly shows the level of oxidative damage (49). The expression of antioxidant-associated genes in the small intestine of mice administered DMG-Na as a prevention or a treatment was increased, compared with mice in the IN group. This is in line with previous studies that suggested natural antioxidants are beneficial in the regulation of antioxidant-associated gene expression $(10,41)$. The current study indicated that the regulation of antioxidant-associated genes following prevention and treatment with DMG-Na may be one possible mechanism by which oxidative damage was reduced and mitochondrial function maintained in the small intestines of mice. Some positive results have been reported in this manuscript, however, further 

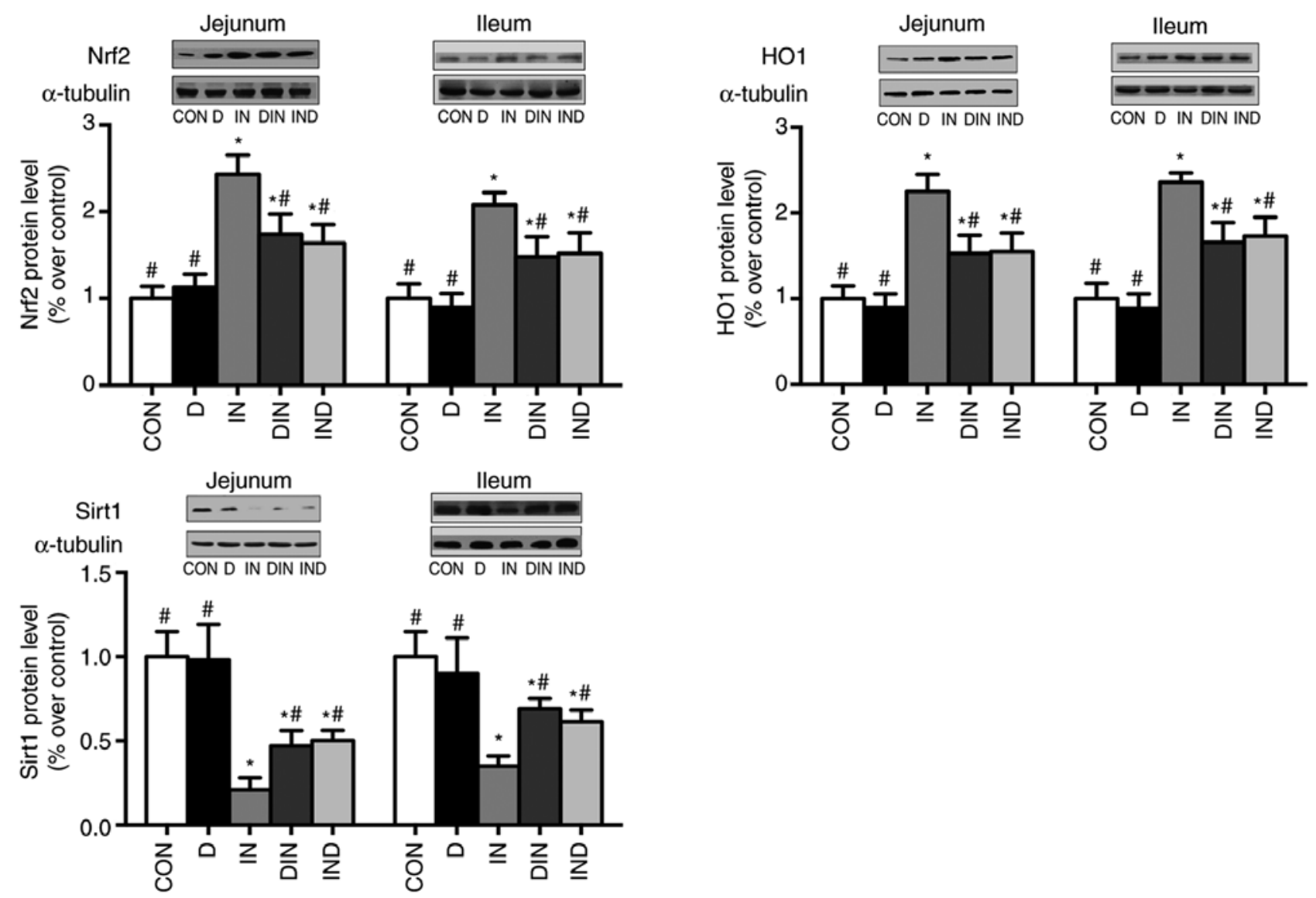

Figure 8. Effects of DMG-Na on Nrf2, HO1, and Sirt1 protein level of small intestine in indomethacin-injected mice. Data are expressed as the mean \pm standard error of the mean $(\mathrm{n}=20)$. ${ }^{\text {P }}<0.05$ vs. CON; ${ }^{*} \mathrm{P}<0.05$ vs. IN. Nrf2, nuclear factor erythroid 2-related factor 2; HO1, heme oxygenase 1; Sirt1, sirtuin 1; DMG-Na, dimethylglycine sodium salt; CON, intubation and injection with saline; D, intubation with DMG-Na and injection with saline; IN, intubation with saline and injection with indomethacin; DIN, intubation with DMG-Na and injection with indomethacin; IND, injection with indomethacin and intubation with DMG-Na.

study is required to determine the specific mechanisms by which DMG-Na improves small intestine damage.

In conclusion, the present study demonstrated that DMG-Na was a potential antioxidant that effectively alleviated indomethacin-induced damage in the small intestines of mice. Both prevention and treatment with DMG-Na scavenged excess ROS, prevented mitochondrial dysfunction and inhibited cell apoptosis that was induced by oxidative damage. It was speculated that DMG-Na directly neutralized the excessive free radicals generated, and acted indirectly to improve the activity of antioxidant enzymes and to inhibit the abnormal expression of stress-associated factors. Of note, the results highlighted that the effects of DMG-Na when administered as a preventative measure were stronger than when DMG-Na was administered as a treatment. This therefore suggested that DMG-Na served as a health-promoting preventative additive and could be used in the field of disease prevention.

\section{Acknowledgements}

Not applicable.

\section{Funding}

No funding was received.

\section{Availability of data and materials}

The datasets used and/or analyzed during the current study are available from the corresponding author on reasonable request.

\section{Authors' contributions}

$\mathrm{KB}$ and $\mathrm{LJ}$ analyzed and interpreted the data. $\mathrm{KB}, \mathrm{LJ}, \mathrm{SZ}, \mathrm{CF}$, $\mathrm{YZ}, \mathrm{LZ}$ and TW performed the experiments, and LJ was a major contributor in writing the manuscript. All authors read and approved the final manuscript.

\section{Ethics approval and consent to participate}

All procedures were approved by the Institutional Animal Care and Use Committee of Nanjing Agricultural University (Nanjing, Jiangsu, China).

\section{Patient consent for publication}

Not applicable.

\section{Competing interests}

The authors declare that they have no competing interests. 


\section{References}

1. Ma K, Zhang Y, Zhu D and Lou Y: Protective effects of asiatic acid against D-galactosamine/lipopolysaccharide-induced hepatotoxicity in hepatocytes and kupffer cells co-cultured system via redox-regulated leukotriene $\mathrm{C} 4$ synthase expression pathway. Eur J Pharmacol 603: 98-107, 2009.

2. Giacco F and Brownlee M: Oxidative stress and diabetic complications. Circ Res 107: 1058-1070, 2010.

3. Balaban RS, Nemoto S and Finkel T: Mitochondria, oxidants, and aging. Cell 120: 483-495, 2005.

4. Inoue J, Miki I, Tanahashi T, Kawauchi S, Azuma T and Mizuno S: Mo2016 Effect of ghrelin on indomethacin-induced Ssmall intestinal injury in mice. Gastroenterology 144 (Suppl 1): S719, 2013

5. Hariganesh $\mathrm{K}$ and Prathiba J: Effect of dimethylglycine on gastric ulcers in rats. J Pharm Pharmacol 52: 1519-1522, 2000.

6. Cupp MJ and Tracy TS: Dimethylglycine (N,N-Dimethylglycine). Dietary Suppl: 149-160, 2003.

7. Pere C and Maria RI: Amino acid-based surfactants: Enzymatic synthesis, properties and potential applications. Cheminform 20 215-233, 2009.

8. Friesen RW, Novak EM, Hasman D and Innis SM: Relationship of dimethylglycine, choline, and betaine with oxoproline in plasma of pregnant women and their newborn infants. J Nutr 137 2641-2646, 2007.

9. Clapes P and Infante MR: Amino acid-based surfactants: Enzymatic synthesis, properties and potential applications. Cheminform 20 215-233, 2009.

10. Bai KW, Xu W, Zhang JF, Kou T, Niu Y, Wan X, Zhang L, Wang $\mathrm{C}$ and Wang $\mathrm{T}$ : Assessment of free radical scavenging activity of dimethylglycine sodium salt and its role in providing protection against lipopolysaccharide-induced oxidative stress in mice. PLoS One 11: e0155393, 2016

11. Ma P, Wu Y, Zeng Q, Gan Y, Chen J, Ye X and Yang X: Oxidative damage induced by chlorpyrifos in the hepatic and renal tissue of Kunming mice and the antioxidant role of vitamin E. Food Chem Toxicol 58: 177-183, 2013.

12. Long M, Yang SH, Han JX, Li P, Zhang Y, Dong S, Chen X, Guo J, Wang J and He JB: The protective effect of grape-seed proanthocyanidin extract on oxidative damage induced by zearalenone in Kunming mice liver. Int J Mol Sci 17: 808, 2016.

13. Long M, Liu Y, Cao Y, Wang N, Dang $M$ and He J: Proanthocyanidins attenuation of chronic lead-induced liver oxidative damage in kunming mice via the Nrf2/ARE pathway. Nutrients 8: E656, 2016.

14. Dong L, Zhong X, He JT, Zhang L, Bai K, Xu W, Wang T and Huang X: Supplementation of tributyrin improves the growth and intestinal digestive and barrier functions in intrauterine growth-restricted piglets. Clin Nutr 35: 399-407, 2016.

15. Panchenko LF, Brusov OS, Gerasimov AM and Loktaeva TD: Intramitochondrial localization and release of rat liver superoxide dismutase. FEBS Lett 55: 84-87, 1975.

16. Lawrence RA and Burk RF: Glutathione peroxidase activity in selenium-deficient rat liver. Biochem Biophys Res Commun 71: 952-958, 1976 .

17. Roediger WE and Truelove SC: Method of preparing isolated colonic epithelial cells (colonocytes) for metabolic studies. Gut 20: 484-488, 1979.

18. Langston JW, Li W, Harrison L and Aw TY: Activation of promoter activity of the catalytic subunit of $\gamma$-glutamylcysteine ligase (GCL) in brain endothelial cells by insulin requires antioxidant response element 4 and altered glycemic status: Implication for GCL expression and GSH synthesis. Free Radic Biol Med 51: 1749-1757, 2011

19. Van Remmen H, Ikeno Y, Hamilton M, Pahlavani M, Wolf N, Thorpe SR, Alderson NL, Baynes JW, Epstein CJ Huang TT, et al: Life-long reduction in MnSOD activity results in increased DNA damage and higher incidence of cancer but does not accelerate aging. Physiol Genomics 16: 29-37, 2003.

20. Botsoglou NA, Fletouris DJ,Papageorgiou GE, Vassilopoulos VN, Mantis AJ and Trakatellis AG: Rapid, sensitive, and specific thiobarbituric acid method for measuring lipid peroxidation in animal tissue, food, and feedstuff samples. J Agric Food Chem 42: 1931-1937, 1994.

21. Wei QY, Chen WF, Zhou B, Yang L and Liu ZL: Inhibition of lipid peroxidation and protein oxidation in rat liver mitochondria by curcumin and its analogues. Biochim Biophys Acta 1760: 70-77, 2006.
22. Sang H, Zhang L and Li J: Anti-benzopyrene-7,8-diol-9,10epoxide induces apoptosis via mitochondrial pathway in human bronchiolar epithelium cells independent of the mitochondria permeability transition pore. Food Chem Toxicol 50: 2417-2423, 2012.

23. Zhang Q, Zou P, Zhan H, Zhang M, Zhang L, Ge RS and Huang Y: Dihydrolipoamide dehydrogenase and cAMP are associated with cadmium-mediated Leydig cell damage. Toxicol Lett 205: 183-189, 2011.

24. Siddhuraju P and Manian S: The antioxidant activity and free radical-scavenging capacity of dietary phenolic extracts from horse gram [Macrotyloma uniflorum (Lam.) Verdc.] seeds. Food Chem 105: 950-958, 2007.

25. Liu H, Jiang Y, Luo Y and Jiang W: A simple and rapid determination of ATP, ADP and AMP concentrations in pericarp tissue of litchi fruit by high performance liquid chromatography. Food Technol Biotechnol 44: 531-534, 2006.

26. Cavelier L, Johannisson A and Gyllensten U: Analysis of mtDNA copy number and composition of single mitochondrial particles using flow cytometry and PCR. Exp Cell Res 259: 79-85, 2000.

27. Liu J, Chen D, Yao Y, Yu B, Mao X, He J, Huang Z and Zheng P: Intrauterine growth retardation increases the susceptibility of pigs to high-fat diet-induced mitochondrial dysfunction in skeletal muscle. PLoS One 7: e34835, 2012.

28. Bhattacharyya A, Chattopadhyay R, Mitra S and Crowe SE: Oxidative stress: An essential factor in the pathogenesis of gastrointestinal mucosal diseases. Physiol Rev 94: 329-354, 2014.

29. Nusrat A, Parkos CA, Verkade P, Foley CS, Liang TW, Innis-Whitehouse W, Eastburn KK and Madara JL: Tight junctions are membrane microdomains. J Cell Sci 113: 1771-1781, 2000.

30. Look MP, Riezler R, Berthold HK, Stabler SP, Schliefer K, Allen RH, Sauerbruch T and Rockstroh JK: Decrease of elevated $\mathrm{N}, \mathrm{N}$-dimethylglycine and $\mathrm{N}$-methylglycine in human immunodeficiency virus infection during short-term highly active antiretroviral therapy. Metabolism 50: 1275-1281, 2001.

31. Bayrak O, Uz E, Bayrak R, Turgut F, Atmaca AF, Sahin S, Yildirim ME, Kaya A, Cimentepe E and Akcay A: Curcumin protects against ischemia/reperfusion injury in rat kidneys. World J Urol 26: 285-291, 2008.

32. Kowaltowski AJ and Vercesi AE: Mitochondrial damage induced by conditions of oxidative stress. Free Radic Biol Med 26: 463-471, 1999

33. Tang Y, Chao G, Xing M, Li Y, Zhu L, Wang D, Yang X, Liu L and Yao P: Quercetin prevents ethanol-induced dyslipidemia and mitochondrial oxidative damage. Food Chem Toxicol 50: 1194-1200, 2012

34. Lee HJ, Oh YK, Rhee M, Lim JY, Hwang JY, Park YS, Kwon Y, Choi KH, Jo I, Park SI, et al: The role of STAT1/IRF-1 on synergistic ROS production and loss of mitochondrial transmembrane potential during hepatic cell death induced by LPS/d-GalN. J Mol Biol 369: 967-984, 2007.

35. Wilhelm EA, Jesse CR, Roman SS, Nogueira CW and Savegnago L: Hepatoprotective effect of 3-alkynyl selenophene on acute liver injury induced by D-galactosamine and lipopolysaccharide. Exp Mol Pathol 87: 20-26, 2009.

36. Chen JJ and Yu BP: Alterations in mitochondrial membrane fluidity by lipid peroxidation products. Free Radic Biol Med 17: 411-418, 1994.

37. Zhang R, Kang KA, Piao MJ, Chang WY, Maeng YH, Chae S, Lee IK, Kim BJ and Hyun JW: Butin reduces oxidative stress-induced mitochondrial dysfunction via scavenging of reactive oxygen species. Food Chem Toxicol 48: 922-927, 2010.

38. Zeng T, Zhang CL, Zhu ZP, Yu LH, Zhao XL and Xie KQ: Diallyl trisulfide (DATS) effectively attenuated oxidative stress-mediated liver injury and hepatic mitochondrial dysfunction in acute ethanol-exposed mice. Toxicology 252: 86-91, 2008.

39. Liu CS, Tsai CS, Kuo CL, Chen HW, Lii CK, Ma YS and Wei YH: Oxidative stress-related alteration of the copy number of mitochondrial DNA in human leukocytes. Free Radic Res 37: 1307-1317, 2003.

40. Morikawa A, Sugiyama T, Kato Y, Koide N, Jiang GZ, Takahashi K, Tamada Y and Yokochi T: Apoptotic cell death in the response of D-galactosamine-sensitized mice to lipopolysaccharide as an experimental endotoxic shock model. Infect Immun 64: 734-738, 1996.

41. Zhang J, Xu L, Zhang L, Ying Z, Su W and Wang T: Curcumin attenuates D-galactosamine/lipopolysaccharide-induced liver injury and mitochondrial dysfunction in mice. J Nutr 144: 1211-1218, 2014. 
42. Kode A, Rajendrasozhan S, Caito S, Yang SR, Megson IL and Rahman I: Resveratrol induces glutathione synthesis by activation of $\mathrm{Nrf} 2$ and protects against cigarette smoke-mediated oxidative stress in human lung epithelial cells. Am J Physiol Lung Cell Mol Physiol 294: L478-L488, 2008.

43. Morse D, Lin L, Choi AM and Ryter SW: Heme oxygenase-1, a critical arbitrator of cell death pathways in lung injury and disease. Free Radic Biol Med 47: 1-12, 2009.

44. Hwang J, Yao H, Caito S, Sundar IK and Rahman I: Redox regulation of sirtl in inflammation and cellular senescence. Free Radic Biol Med 61: 95-110, 2013.

45. Holmgren A, Johansson C, Berndt C, Lönn ME, Hudemann C and Lillig $\mathrm{CH}$ : Thiol redox control via thioredoxin and glutaredoxin systems. Biochem Soc Trans 33: 1375-1377, 2005.

46. Pérez VI, Lew CM, Cortez LA, Webb CR, Rodriguez M, Liu Y, Qi W, Li Y, Chaudhuri A, Van Remmen H, et al: Thioredoxin 2 haploinsufficiency in mice results in impaired mitochondrial function and increased oxidative stress. Free Radic Biol Med 44: 882-892, 2008.
47. Michelet L, Zaffagnini M, Massot V, Keryer E, Vanacker $\mathrm{H}$, Miginiac-Maslow M, Issakidis-Bourguet E and Lemaire SD: Thioredoxins, glutaredoxins, and glutathionylation: New crosstalks to explore. Photosynth Res 89: 225-245, 2006.

48. Zeissig S, Bürgel N, Günzel D, Richter J, Mankertz J, Wahnschaffe U,Kroesen AJ,Zeitz M,Fromm M and Schulzke JD: Changes in expression and distribution of claudin 2,5 and 8 lead to discontinuous tight junctions and barrier dysfunction in active Crohn's disease. Gut 56: 61-72, 2007.

49. Gu L, Li N, Gong J, Li Q, Zhu W and Li J: Berberine ameliorates intestinal epithelial tight-junction damage and down-regulates myosin light chain kinase pathways in a mouse model of endotoxinemia. J Infect Dis 203: 1602-1612, 2011. 